Adelajda Sielepin CHR

\title{
Biskup Wacław Świerzawski
}

Bp prof. dr hab. Wacław Józef Świerzawski urodził się 14 maja 1927 roku w Złoczowie w archidiecezji lwowskiej. Jego wstępna edukacja przypadła na lata wojenne i zakończyła się maturą uzyskaną w 1944 roku na tajnych kompletach w liceum humanistycznym. Nieoficjalny, ale istotny początek drogi duchowej wybitnego liturgisty zarysował się w bardzo młodym wieku w jego posłudze ministranta podjętej od dziecięcych lat, wytrwałej nauce łaciny u ówczesnego katechety ks. Jana Cieńskiego oraz w posłudze kościelnego w rodzinnej parafii w Złoczowie (1943-1944). Formacja teologiczna i liturgiczna Jubilata rozpoczęła się formalnie w Wyższym Seminarium Duchownym we Lwowie, które w 1945 roku zostało przeniesione do Kalwarii Zebrzydowskiej. Ten pierwszy okres został uwieńczony święceniami kapłańskimi przyjętymi 11 grudnia 1949 roku z rąk Arcybiskupa Metropolity Lwowskiego Eugeniusza Baziaka w Kalwarii Zebrzydowskiej.

Drugi etap obejmuje dojrzewanie młodego pasterza i naukowca aż do czasu objęcia funkcji rektora kościoła św. Marka w Krakowie (1968). Łącząc świadomie te dwie dziedziny kapłańskiego życia, przypomina Ojców Kościoła - pierwszych teologów i mystagogów prowadzących ludzi ku Chrystusowi. Po święceniach pracował jako wikariusz w Cieszanowie, „reszcie” rodzimej archidiecezji, a potem w Nysie w katedrze św. Jakuba Apostoła. Pomimo głębokiego pragnienia studiów liturgicznych zgodnie z wolą biskupa rozpoczął studia prawnicze, które ukończył w 1954 roku w Warszawie, a przez ten czas w pobliskiej Zielonce był kapelanem sióstr dominikanek misjonarek, jednocześnie prowadząc duchową formację świeckich. Owocem tej posługi był instytut świecki powołany do istnienia w 1956 roku jako odważny początek wspólnot konsekrowanych, których jest założycielem. Aktualnie są to dwa instytuty świeckie (1956, 1970), Zgromadzenie Sióstr św. Jadwigi Królowej Służebnic Chrystusa Obecnego (1990) i Instytut Kapłanów Chrystusa Paschalnego (2000). W okresie warszawskim zetknął się też ks. Świerzawski z nurtem polskiej odnowy liturgicznej i jej przedstawicielami w Laskach. Sam jednak doświadczył spełnienia swoich pragnień w tej dziedzinie, kiedy w roku 1966 został skierowany na studia 
liturgiczne do benedyktyńskiego Instytutu św. Anzelma w Rzymie, które w 1968 roku zakończył doktoratem pt. Faith and Worship in the Pauline Commentaries of Saint Thomas Aquinas. Od tego momentu rozpoczęła się u ks. Świerzawskiego jednoznaczna droga liturgisty-mystagoga - uczonego i przewodnika po ścieżkach duchowości liturgicznej.

Po studiach rzymskich wrócił do Krakowa i zaraz otrzymał zadanie od ówczesnego metropolity kard. Karola Wojtyły, by stworzyć przy Wydziale Teologicznym Instytut Liturgiczny, który stał się wkrótce liturgiczną szkołą promującą i realizującą założenia soborowej konstytucji o liturgii w trzech dziedzinach: teologii, sztuki i muzyki. Od początku instytut jako placówka edukacyjno-formacyjna był związany z uczelnią teologiczną i kościołem. Był to zawsze Wydział Teologiczny (najpierw samodzielny, od 1981 roku w ramach Papieskiej Akademii Teologicznej, a od 2009 roku na Uniwersytecie Papieskim Jana Pawła II) i kościół św. Marka Ewangelisty w Krakowie, który miał stanowić podstawową i nieodzowną dla studiów liturgicznych niwę liturgiczną i duszpasterską o tymże profilu. Ks. Świerzawski jako wykładowca doskonalił swój warsztat uczonego na Wydziale Teologicznym, czego dowodem jest rozprawa habilitacyjna na temat anamnezy eucharystycznej pt. Dynamiczna „pamiatka” Pana. Eucharystyczna anamneza Misterium Paschalnego i jego egzystencjalna dynamika i późniejsze liczne książki (66) oraz artykuły (1,3 tys.) z dziedziny teologii liturgii, duchowości i homiletyki. Po uzyskaniu habilitacji w 1975 roku ks. Wacław Świerzawski został kierownikiem katedry teologii liturgii i kuratorem katedry homiletyki. W roku 1981 uzyskał tytuł profesora nadzwyczajnego, a w 1989 - profesora zwyczajnego, zostając dodatkowo kuratorem katedry teologii życia wewnętrznego. Swoje doświadczenia ubogacał zdobyczami innych ośrodków liturgicznych, duszpasterskich i naukowych w Europie i Stanach Zjednoczonych, organizując i uczestnicząc w licznych sympozjach naukowych i sam wizytując te miejsca. W tym czasie jako rektor kościoła i dyrektor instytutu rozwijał scaloną mystagogię liturgiczną, począwszy od kapłanów studiujących w instytucie, poprzez konsekrowanych i świeckich aż po nieochrzczonych. Dokonywało się to poprzez systematyczne życie liturgiczne (Eucharystia, liturgia godzin, katechezy mystagogiczne, rekolekcje przygotowujące do przyjęcia sakramentu chorych, katechumenat) i formację (kurs dla zakrystianów, wykłady z duchowości liturgicznej, studium katechumenalne). Swoim talentem organizacyjnym i mystagogicznym mógł posłużyć całej uczelni, będąc dwukrotnie (1988 i 1991) wybierany na rektora Papieskiej Akademii Teologicznej w Krakowie. Druga kadencja została przerwana w 1992 roku powołaniem profesora przez Ojca świętego Jana Pawła II na stolicę biskupią w Sandomierzu. 
Etap krakowski nie byłby pełny bez odniesienia do dwóch świętych, których biskup odkrył w sposób charyzmatyczny. Są to: Michał Giedroyć, zakrystian kościoła św. Marka († 1485) i królowa Jadwiga Wawelska, fundatorka Wydziału Teologicznego i jego patronka (†1399). Bł. Michał stał się ważnym orędownikiem i patronem Instytutu Liturgicznego. Jemu ks. Świerzawski poświęcał sesje naukowe i przybliżał na nowo środowisku teologów przez nowennę lat i miesięcy zwieńczoną ogólnopolskimi obchodami pięćsetlecia jego śmierci w Krakowie z udziałem biskupów Europy i prymasa Polski. Przyczynił się też istotnie do rozpoczęcia procesu kanonizacyjnego tego świątobliwego zakonnika. Św. Jadwiga stała się mu bliższa podczas pełnienia funkcji rektora akademii i ją jako fundatorkę Wydziału Teologicznego potraktował jako inspiratorkę misji papieskiej uczelni, co wyraziło się w uzupełnionej za kadencji księdza profesora dewizie uczelni: Euntes docete. Jadwigę, która była wybitną promotorką ewangelizacji i obrończynią chrześcijańskiej godności człowieka, wybrał też na patronkę założonego przez siebie zgromadzenia sióstr jadwiżanek.

Czas pasterzowania w diecezji sandomierskiej obejmujący lata 19922002 przypadł na tworzenie nowej wspólnoty Kościoła lokalnego po nowym podziale administracyjnym diecezji w Polsce. W tych okolicznościach opatrznościowa okazała się duchowość liturgiczna, jaką przyniósł w swojej osobie nowy pasterz, i program jednoczenia w Chrystusie, który w dniu swojej sakry biskupiej 28 kwietnia 1992 roku określił jednym słowem: Eucharystia. Tworzenie nowej wspólnoty diecezjalnej rozpoczął od wszechstronnej troski o świadomą i światłą wiarę przez kształcenie wiernych i modlitwę liturgiczną, poczynając od życia liturgicznego w katedrze. Powołał do istnienia Instytut Teologiczny wraz z Diecezjalnym Studium Organistowskim w Sandomierzu (1992), Ludowy Uniwersytet Katolicki im. ks. Konstantego Michalskiego w Staszowie (1994), Modliborzycach (1995), Nisku (1995) i Łagowie Opatowskim (1997) oraz wiele instytucji dla budowania życia chrześcijańskiego na terenie całej diecezji. Należą do nich ośrodki charytatywne, Stowarzyszenia Młodzieży i Rodzin Katolickich, Akcja Katolicka, katolickie domy kultury, licea katolickie. Idąc śladem św. Jadwigi troszczył się o wykształcenie kapłanów, kierując wielu na studia specjalistyczne w kraju i za granicą. Z działań typowo duszpasterskich na pierwszym miejscu trzeba wspomnieć Ośrodek Katechumenalny dla Diecezji Sandomierskiej przy katedrze (1993), diecezjalny Kongres Eucharystyczny (1997) i Drugi Synod Diecezji (1996-1999). Typowo wspólnototwórcze inicjatywy księdza biskupa polegały na gromadzeniu ludzi różnych stanów dla wspólnej wymiany myśli i na liturgii. Od 1997 wprowadził zebrania naukowe w Wyższym Seminarium Duchownym w Sandomierzu, a od 1994 
konwersatoria Communio et communicatio dla duchowieństwa i świeckich na tematy duszpasterskie. Nie zaniedbał też samego centrum jedności, jakim jest Chrystus obecny w Najświętszym Sakramencie, wprowadzając w 1994 roku wieczystą adorację w kościele św. Ducha w Sandomierzu.

Jako biskup dalej angażował się w działalność episkopatu Polski, szczególnie w sprawach dotyczących liturgii. Przez dwie kadencje (1994-1997 i 1997-2000) był przewodniczącym Komisji Kultu Bożego i Dyscypliny Sakramentów Episkopatu Polski. Organizował wtedy coroczne sympozja z duchowości i duszpasterstwa liturgicznego dla osób konsekrowanych na Jasnej Górze, a dla duszpasterzy - w Krakowie i w Sandomierzu. Od roku 1994 był członkiem Komisji Duszpasterskiej, a od roku 1997 - członkiem Komisji Naukowej Episkopatu Polski. Od roku 1994 jest członkiem watykańskiej Kongregacji Kultu Bożego i Dyscypliny Sakramentów. Do pełni kapłańskiego obrazu Jubilata streszczonego dewizą Apostolus Jesu Christi i umieszczoną w biskupim herbie dochodzi szczególna łaska: diamentowy jubileusz jego święceń przypada w Roku Kapłańskim, którego patronem jest święty proboszcz z Ars, pasterz, nauczyciel i hojny szafarz Słowa i Ciała Chrystusa obecnego w Eucharystii. 